\title{
IN MEMORY OF PROF. DR. MARCO VITTORIO COVASSI
}

On the 11th of April 2020, a Holy Saturday, beloved Marco Vittorio Covassi passed away peacefully. The Director of the former Istituto Sperimentale per la Zoologia Agraria of Florence, Academician Emeritus of the Italian National Academy of Entomology and of the Italian Academy of Forestry Sciences, Member of the Italian Entomological Society.

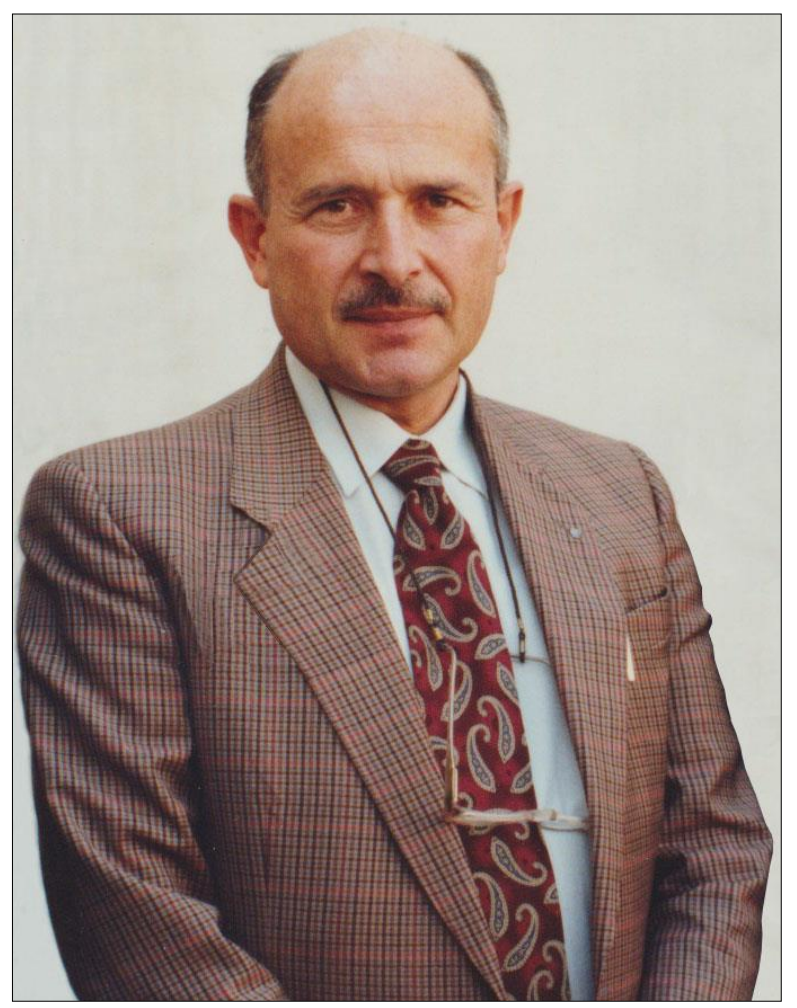

M. V. Covassi was one of the pioneers of Italian Forest Entomology. A tireless researcher, passionate scholar of the subject matter, indefatigable hiker and irreplaceable observer and investigator, in the woods, of the state of health and the degree of sustainability of forest ecosystems. He was also an authoritative and undisputed teacher, for the breadth of his specific skills and more, for many students, colleagues and friends who had the good fortune to know him thoroughly, to learn from him and to work and collaborate with him.

A son, in love with his beautiful homeland, Carnia, Marco V. Covassi was born in Ovaro, in the Province of Udine, on December 3, 1937. Third son of Dr. Luigi Covassi, doctor in charge of the town and the neighbouring hamlets, and of Teresa Cecchetti. The paternal home is a small cottage surrounded by green meadows not far from the coniferous forests of the surrounding mountains. Since he was a boy, Marco shows a strong aptitude for natural sciences of which he will become an allround enthusiast, stimulated in this by the beauty of the nature of his region. After graduating as an Agricultural
Expert at the School of Viticulture and Enology of Conegliano Veneto (TV) in 1957, he joins as a fellow graduate the Senior School of Applied Sciences in Pisa, "A. Pacinotti” (later known as Saint Anna Senior School of Applied Sciences and Advanced Studies). At the same University he was a student of the Institute of Agricultural Entomology from 1958 to 1961, the year in which, on 6 December, he graduated in Agricultural Sciences with the highest marks and honours.

The thesis, discussed with Prof. Filippo Venturi, is entitled "Osservazioni sulla minatrice degli aghi dell'abete rosso in Carnia, Epiblema tedella (Lepidoptera Tortricidae)". Upon presentation of his thesis, on December 16 of the same year, he moved to Florence in the position of Assistant Volunteer in the Department of Forest Zoology, Hunting and Aquaculture of the University run by Prof. Rodolfo Zocchi and at the same time enrolled in the 2 year degree course in Forestry Sciences. The post of assistant was held by him for more than ten years until October 31, 1973. This position, together with being under Zocchi's example and guidance, definitely introduced him to the world of forest entomology of which he would become, more and more, an accurate researcher and talented scholar.

After completing his military service, which began in January 1964, he takes his leave with the rank of Second Lieutenant in the infantry (XIII Btg. Ftr. Missili) in April 1965.

In July of the same year he graduated in Forestry Sciences at the University of Florence, always with top marks and honours discussing with Prof. Zocchi the thesis entitled 'Contributo alla conoscenza dell'Entomofauna del Gen. Juniperus in Italia". From the 1st of January 1966, he entered into service as a fellow graduate at the Agricultural Entomology Centre of the Ministry of Agriculture and Forests in Florence.

After the reform of pre-existing structures of the M.A.F. changed into new entities in the "Instituti di Ricerca e Sperimentazione Agraria" (I.R.S.A.) (DPR 1318/67), since December 1967 he has been a tenured Researcher at the new Instituto Sperimentale per la Zoologia Agraria of Florence (I.S.Z.A.), assigned to the Forest Entomology Section, a position he held for a decade until September 1977.

It is in this period that, following the indications of Prof. Zocchi who for some time, after Giacomo Cecconi, has been a constant facilitator in Italy of forest entomology studies, he turns his first activity as a researcher to the study of insects potentially harmful to the Douglas fir (Pseudotsuga menziesii). In fact, this conifer, among the nearctic species introduced in Italy for silvicultural and economic purposes, had been widely spread in the central-northern Apennine region.

In this context, starting from 1967, he published his first works on some weevils (Curculionidae) harmful to 
the conifer in Tuscany, in the Pratomagno area, belonging to the genera Strophosomus, Polydrosus and Otiorrhinchus. Of the three species investigated and recognised as harmful, S. Melanogrammus, P. Marginatus and $O$. armadillo, he reports extensive information on the spread, ethology and damage caused. In the same period he was entrusted, again by the Director Zocchi, with the continuation of the study of the entomofauna of junipers, already the subject of his thesis, to which he will dedicate a few years of intense work with scrupulous passion and commitment that will lead him to print, in the 1969, a first major contribution on two xylophagous longhorned beetles (Cerambycidae) belonging to genus Semanotus. Of the two species investigated, S. russicus and S. laurasi, he reports very accurately the geonemy known until then, followed by equally accurate information on the main aspects of morphology, bio-ecology and ethology, as well as on the damage found on host plants, these mainly belonging to junipers and, in North Africa, also to the Atlas cedar.

In the same period, always in the continuation of the investigations on the xylophagous entomofauna of junipers he publishes in Redia (1968), in collaboration with Rodolfo Zocchi, a new contribution on the phytosanitary importance of a species until then not well known, the Phymatodes glabratus, a topic that the Authors re-presented at the VIII Italian National Congress of Entomology held in Florence in September 1969.

In the years 1970-1971, in the context of research on insects harmful to Douglas fir, his attention was focused on the study of an aphid species recently introduced in Italy, the nearctic woolly aphid, Gilletteella coweni (Adelgidae) which shows to be harmful especially in seedlings of forest nurseries and in young plantations. On this species he publishes two works on the Annals of the Institute, one on the bio-ecology of that sap-sucking insect, the other on the results of some chemical control tests against the same adelgid, carried out in "Il Capannone", near Maresca, a forest nursery in Pistoia Province.

In 1971 he publishes documented news on Redia on the discovery in Italy of another harmful tree aphid, introduced from North Africa. This time it is a species harmful to cedars, trees of primary importance among ornamental plants in parks and gardens. It is the lachnid Cedrobium laportei of which it provides an accurate overview of the retrieval locations in Italy with preliminary information on the biology and the real impact of the aphid on the health status of the infested plants. In fact, there is confirmation that in addition to the Atlas cedar, the cedar of Lebanon is also affected and that the intense infestations of this sap-sucking insect can lead the plants to complete defoliation, up to their total desiccation, at the same time favouring the development of abundant sooty mould fungi.

A new contribution on Redia is dated 1973, together with Prof. Luigi Masutti, concerning the discovery and diffusion in the pine forests of the Alps and central-eastern Pre-Alps of the needle shortening gall midge, Thecodiplosis brachyntera (Diptera Cecidomyiidae) known to induce deformations on the needles of the affected plants, in particular of the Scotch pine. The following year, M. Covassi announces, again on Redia, the discovery, in the Botanical Garden of the University of Florence, of an alien weevil species of Australian origin, harmful to the Cicadaceae, the Demyrsus meleoides. Of this species it provides the main distinctive characteristics of the adult and the larva. Almost simultaneously, in collaboration with the writer, he reports in the same magazine about the discovery in Italy of another conifer lachnid linked to cedars, Cinara cedri. This aphid species is reported for the first time not only in our country but also for Europe since until then it was known only for Morocco and Turkey. The Authors report on the spread of the new aphid in Italy by providing the morphological description of the aptera and alata vivipara together with a key to distinguish it from Cedrobium laportei. As part of the awareness of the importance of the geonemy of sap-sucking insects for forestry, in 1975 he publishes, again in Redia, an update on the spread of the woolly beech scale Cryptococcus fagisuga, an insect associated to the beech tree, whose presence in Sicily and Corsica is reported for the first time.

In 1977 Marco Covassi won the competition for the Director of Departments of the I.R.S.A. and in September of the same year, he was newly appointed Director of Forest Entomology Section of the I.S.Z.A. After the three year first contract period he obtained confirmation as Ordinary Director of the Department, a position he held until February 1994.

In 1978, the Section Director Covassi and his "colleague', and dear friend, Luigi Masutti, Professor of the University of Padua and well-known professor of Forest Zoology, Hunting and Aquaculture, published in the I.S.Z.A. journal, an impressive, detailed work on the sawflies of the forest and mountain habitats of Friuli (Hymenoptera Symphyta). The work is the result of many years of surveys on the entomofauna in that region. 90 species are treated, of which seventeen reported for the first time in Italy. For each of them the Authors provide collection data and very accurate information on geonemy and eco-ethology by discussing their respective relationships with their living environment under the biogeographical and silvicultural aspect. For some species of more problematic discrimination belonging to the genera Gilpinia and Hoplocampa, morphological data relating to the male and female genitals are provided. Following this work the same Authors two years later, in Redia (1980), release a new contribution on the knowledge of the Italian Hoplocampa with the description of a new species, $H$. chamaemespili, associated to the same Sorbus. The work is accompanied by a dichotomic key for the recognition of the Italian and European-Western Hoplocampa.

In the early 1980's (1982/83 - 1983/84), by request of the Faculty Council, Marco held the fundamental teaching post of Forest Zoology, Hunting and Aquaculture at the University of Florence, as a contract lecturer.

At the same time, the early 1980's saw him engaged on several fronts in the context of the implementation of knowledge of species harmful to forest plants. In 1980 (Redia), following a new epidemic of the Dutch elm disease he reports the discovery, on Ulmus carpinifolia, of a new bark beetle for Italy, the Scolytus kirschi, which 
together with other congeneric species is involved in the spread of the pathogen. In 1983 (Redia) a memo was published on a gall midge of the silver fir, the Cecidomyiid Paradiplosis abietis, found in the native firs of Calabria at the southern limit of the conifer distribution area, while in 1986 (Redia) the first information comes out (in coll.with G. Poggesi) on the presence and activity of some predatory Anthocorids of scales of the gen. Matsucoccus, in particular, of Elatophilus pini, new to Italy.

In recent years, the problem of the maritime pine bast scale, the Margarodid Matsucoccus feytaudi, has come to the attention of the Italian forestry experts and researchers, which from neighbouring France is advancing towards the east, devastating in an impressive way the native populations of the host conifer, the Pinus pinaster. It was known especially from the French literature, an argument already extensively available, that the bast scale was endemic to the Atlantic populations of its host pine and that in those territories did not cause any damage as it co-evolved with its host. But the accidental introduction of the same scale in the Mediterranean area of south-eastern France which occurred around the 1950s had created and favoured abnormal demographic increases of the scale insect and determined extensive phenomena of deterioration of the maritime pine forests up to the complete destruction, in a span of twenty years, of over 120,000 ha of populations in the Provence region. Already in the early 1970s both Covassi (1970) and Masutti (1973) and other Italian Authors warn about a possible and devastating encroachment in the Ligurian territory of the bast scale, capable of advancing for about $6 \mathrm{~km}$ a year as stated by the French researchers.

The first damages after the encroachment is observed in western Liguria in the winter of 1977-78 in Monte Nero di Bordighera in the province of Imperia. From those years onwards Marco Covassi, in the role of forest entomologist of the I.S.Z.A., responsible for the sector's expertise, promoted numerous research projects funded by the Ministry and other Bodies for the study and possible control of the epidemic scale attack which is inexorable for the health of the maritime pine in our home territory.

The research sees him engaged on the front line together with his closest collaborators including myself. The first work, signed by Covassi and Binazzi, which takes stock of the situation under multiple aspects, is dated 1987 and is published in the Proceedings of the "Conference on the Adversities of the Woods and Wood Tree Species" which takes place in Florence on 15 - 16 October, 1987 under the aegis of the Italian National Academy of Entomology and the Italian Academy of Forest Sciences. The work outlines the main information on the bio-ecology of the insect, on its current diffusion, on the methods used for sampling, on the collection of biological and faunal data concerning the main entomatic antagonists_of the Margarodid found in the area, on the xylophagous insects involved in decay initiated by the scale_and on the general criteria for the control of infestations by means of good silvicultural techniques.

All the research on the Matsucoccus subject on the part of M. Covassi and his collaborators, occupies about twenty years of intense work and is contained in the attached list of publications, from 1986 to 2006.

Simultaneously with the research on M. feytaudi, M. Covassi enthusiastically adheres to the request, received by the Forestry Company of the Friuli Venice-Giulia Region, to participate in the preliminary studies on the faunal aspects of the Rio Alba Valley, in the Municipality of Moggio Udinese in the Province of Udine. The Company's intention is to create a Nature Reserve of the Val d'Alba in the area of this Rio. For Marco it is like coming home to his mountains. The research conducted over the course of three years is carried out by the entire team of the Forest Section of the I.S.Z.A. and, together with the contributions of other zoologists, inclu-ding Luigi Masutti, the final result is the publication of a volume, dated May 1987, which contains all the research work of the specialists involved. M. Covassi is the $\mathrm{Au}-$ thor and co-Author of the chapter "Aspetti dell'Entomofauna forestale. Gli Insetti fitofagi del Pino nero d'Austria, gli Afidi delle conifere ed altri reperti entomologici" (pp. 17-56).

The 70s and 90s see M. Covassi involved and strongly engaged in two other major research areas, one on cypress insects and one on entomofauna of the silver fir.

On the first research topic, he publishes, individually and in collaboration, numerous contributions that see the press in the period between 1975 and 1998 (see the list of publications).

In particular, in 1991, he reports on a bark beetle linked to the cypress, new to Italy, Phloeosinus armatus, a species from the eastern Mediterranean area, found in various locations in western Liguria.

From the series of works mentioned above, what can rightly be indicated as the compendium of the aforementioned researches is represented by the publication "Il nostro amico cipresso" edited by P.F. Roversi and M.V. Covassi - Atti della Giornata di Studio e Aggiornamento sulle Avversità del Cupressus sempervirens L., - held in Florence on May 14, 1998, published in Vol. XLVII in the Annals of the Italian Academy of Forest Sciences. This compendium takes stock of the main species of cypress insects and their phytosanitary importance, in particular, the lachnid aphid Cinara $\mathrm{cu}$ pressi and the most common xylophagous species, divided into categories based on their bio-ecological plasticity such as, Semanotus russicus, Palmar festiva, Anthaxia passerinii, Phloeosinus aubei, Phl. armatus, Kalotermes flavicollis and others.

In line with the research, already started many years earlier (early 1980s), on the phytophagous insects of Abies alba, M. Covassi and A. Binazzi, present a preview of two reports, one at the $\mathrm{XIV}^{\circ}$ and the other at the $\mathrm{XV}{ }^{\circ}$ National Congress of Entomology which take place respectively in 1985 in Palermo, Erice and Bagheria and, in 1988, in L'Aquila. In these the Authors present the first disclosure of the insects found on the silver fir, including some species of adelgids, the Dreyfusia entities that for our country were unknown to most, both in terms of number of species and as diffusion throughout the territory as well as possible harmful elements for the host conifer. 
The cycle of research on the species of gen. Dreyfusia ends after a decade of surveys carried out along all the native firs of the peninsula. On this subject, notable work under two names is published in Redia (Binazzi \& Covassi, 1991) which summarizes in a sufficiently comprehensive way, at the various levels, all the knowledge obtained for our country on the group of the sap-suckers in question with the description of a new species. Five species of Dreyfusia are treated, four found on silver fir, $D$. piceae, D. prelli, D. merkeri, D. nordmannianae and one described as new, D. nebrodensis, found in Sicily (Madonie) on the Nebrod fir, A. nebrodensis.

However, the research on silver fir insects does not end there. On Redia (1994), Marco Covassi publishes an annotation on the bio-ecology of the bud feeding moth Epinotia nigricana (Lepidoptera Tortricidae) and another annotation on the twig mining moth Argyresthia illuminatella (Lepidoptera Argyresthiidae) (in coll. with V. Francardi).

Other lines of research not less researched by $\mathrm{M}$. Covassi are those aimed at entomofauna of the genera Pinus and Quercus.

On the first group of forest plants, he published in Redia (1989) a contribution regarding the macroscopic modifications of the foliar apparatus caused by the spittlebug Haematoloma dorsatum, (Homoptera Cercopidae) also harmful to other conifers (in coll. with P.F. Roversi and P. Toccafondi). The topic was re-proposed at the conference on "Study Days on the Adversities of the Pine" (Ravenna, 6-7 November 1989). Other contributions to the study of pine insects are those presented at the $\mathrm{XVI}^{\circ}$ National Congress of Entomology held in Bari, Martina Franca (23-28 September 1991) on the species of the genera Magdalis and Pissodes (in coll. with A. Battisti) and the excursus "Problematiche entomologiche delle Pinete di Monte Morello, Firenze” published in L'Italia Forestale e Montana (1995). In this work (in coll. with P.F. Roversi) the possible greater harm, for those populations of black pine, of the homopteran Matsucoccus pini and the bark beetle Tomicus minor is highlighted. Contributions to the knowledge of the aphid species of the mountain pine and the heldreich pine, in collaboration, respectively, with A. Binazzi and Fabrizio Pennacchio (1996) and A. Binazzi (1998) should also be mentioned (see list of publications). Also worth mentioning is the work, published in the Appendix to Redia 2006, "I coleotteri xilofagi dei popolamenti di pino marittimo della Liguria e della Toscana attaccati da Matsucoccus feytaudi" (in coll. with the team of the Forest Entomology Section).

On the line of research dedicated to oaks, the contribution on xylophagous insects presented at the conference "Fitopatological problems of the gen. Quercus in Italy" (Florence 19-20 November 1990), in collaboration with A. Battisti. Finally, mention should be made of the organization of the Conference "Forest Plants, Biotic Adversities and Biological and Integrated Control Perspectives", held in Florence on March 5, 1992, as part of the research project "Biological and integrated fight for the defense of agricultural crops and Forest Plants" (funded by the M.A.F), with Rodolfo Zocchi and Antonio Quacquarelli being the General Coordinators.
For the sub-project of the "Forest Plants" M. Covassi is the Coordinator. His introductory report, followed by two interventions, has additional names on the predatory insects of M. feytaudi in Liguria and on the use of sexual attractants for the monitoring of the green oak moth (Tortrix viridana) in Tuscany.

In this period there is no lack of a further contribution to the knowledge of juniper insects. In fact, in 1992, an accurate work is published in Redia on the bio-ecology of a scale harmful to Juniperus spp. in Tuscany, the Planococcus vovae (in coll. with V. Francardi). The aforementioned species has been found on J. Communis, J. Oxycedrus and ornamental J. Chinensis on which it can cause the branches to dry out with the production of abundant honeydew and the development of copious sooty mould fungi.

In 1992 Rodolfo Zocchi left the management of the I.S.Z.A. for having reached retirement age, making the post of Directorate of the Institute vacant. In a short time, the vigilant Ministry announces the national competition for applicants to fill the post of Director of the "Instituto Sperimentale per la Zoologia Agraria of Florence".

In 1993, first in the aforementioned competition, Marco Covassi was the newly appointed Director of the same Institute starting from February 1994. After the three-year first contract period, he assumed the role of Ordinary Director, a role he held until 31 March 2003. In fact, on the first of April of the same year he is placed on retirement.

The decade of the management of the I.S.Z.A. forced Marco, despite himself, into a role substantially different from that of pure and applied research, which up to that date had been his predominant activity, also considering the fact that the research of those years had managed to remain fairly free from constraints and bureaucratic shackles as well as from the slavery of "pen pushers". Furthermore, in the "Zocchi Era" the number of permanent staff serving at the Institute was reduced. However, when M. Covassi filled the role of Director, things changed on all fronts both in terms of the numerical growth of personnel and in terms of increased bureaucracy on organizational and administrative matters, which became increasingly complicated, with the consequent increase in personal responsibilities inevitably linked to the management activity. In any case, M. Covassi also in his new role manages to give the best of himself and keep the good name of the I.S.Z.A. because the high standard and prestige of the Institute always remained for him the primary purpose of his work commitment. During the period of Ordinary Director M. Covassi was Managing Director of Redia, the magazine of Zoology founded by Antonio Berlese in 1903 which reached, with the volume LXXXVI of 2003, the centenary of its foundation. He was also the Managing Director of the scientific journal "Apicoltura".

In addition to participating in numerous national and international Symposia and Congresses of Entomology, Marco was a member of the Scientific Committee of the $\mathrm{XX}^{\circ}$ International Congress of Entomology held in Florence from 25 to 31 August 1996.

As it is evident from his scientific career that the 


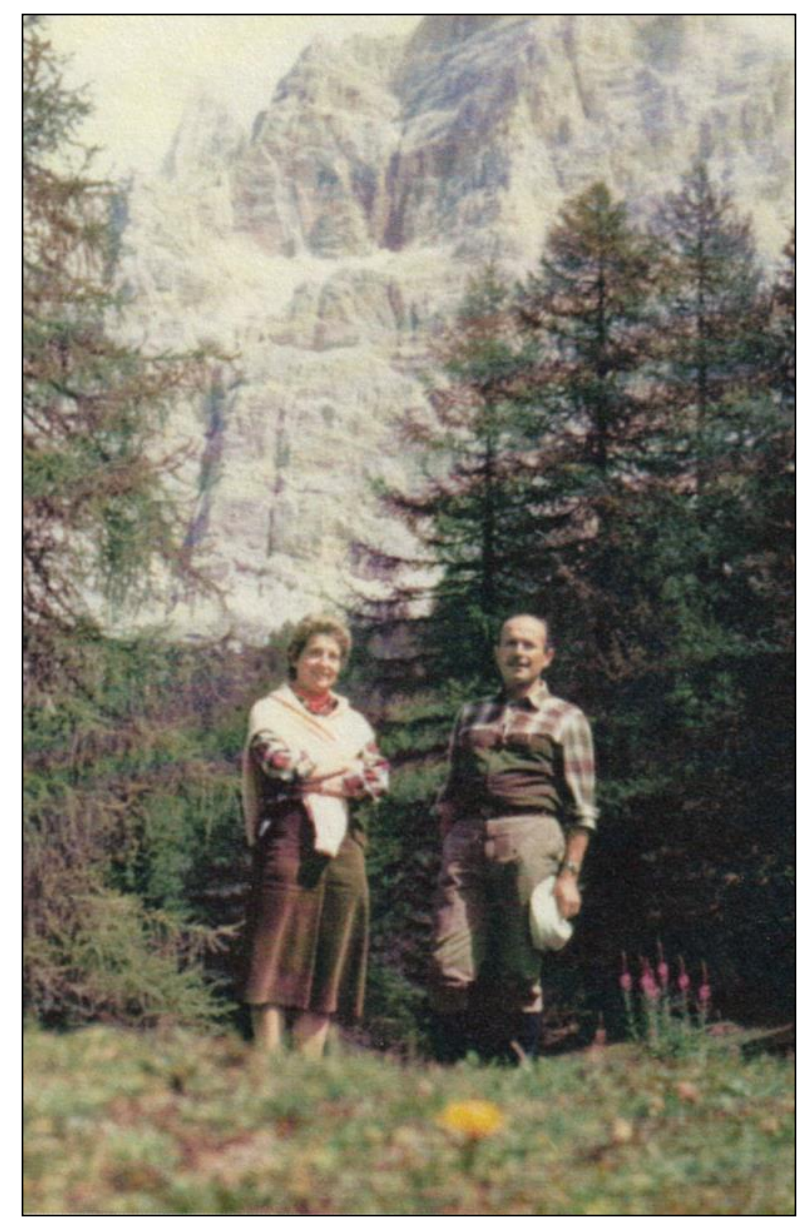

writer has attempted to summarize on the basis of the main lines of research and study, it can be stated that in general M. Covassi has had commending results on the basic and applied themes to the entomofaunas of forest plants present in the variegated ecosystems of the changing Italian landscape.

The aforementioned studies have led him from time to time to tirelessly traveling through the woods and forests of Italy, from the Alps to the Apennines, along the coastal arboreal coenosis of the Peninsula and the main islands, not neglecting meticulous excursions in the woods of the mountains of the oriental Alps and his beloved Carnia.

His research has been aimed at both basic and applied studies, the latter aimed at the development of operational guidelines for the integrated control of the main pests of forest plants, as we have tried to outline by retracing the entire cycle of his research activity. The application aspects that emerge are always framed with the aim of achieving useful results for the prevention or direct control of the most feared and harmful phytophagous species, through the use of environmentally friendly means and technologies. All this without ever neglecting the important contribution of the natural control of phytophagous insects implemented by the amount of predators and parasitoids, native or imported, our auxiliaries, and the possibility of implementing their use and effectiveness in the context of maintenance or restoration of the biocenotic equilibria subject to periodic or occasional imbalances.

His activity as a scholar and researcher was carried out mainly in collaboration primarily with colleagues from the forestry team of the I.S.Z.A. but also with numerous other scholars, both Italian and foreign, who have always welcomed his co-operation favourably, and often with gratitude.

$\mathrm{He}$ is the Author and Co-Author of over ninety publications, including scientific contributions and monographic papers, both in national and international journals.

The memory of Marco cannot conclude only in retracing the salient stages of his professional activity but also in shedding light on the equally many aspects of his private life outside work. Marco was primarily a man of faith, a fervent Catholic. His faith was genuine, sincere, simple, and at the same time problematic, but always anchored on solid principles.

His deep knowledge of the natural world, with all its various aspects of beauty and complexity, even contradictory and often dramatic, did not prevent him from retaining that primitive amazement and sense of admiration for those who perceive in the immensity and mystery of that which surrounds us, the Creator God, the God of Love, Source and Lover of life.

Until the 1960's, when he settled in Florence, he joined the Association of "Laureati Cattolici" later known as "Movimento Ecclesiale di Ispirazione Cattolica" of which he was President and always remained an active and faithful associate.

He frequented the monastic community of the Badia Fiorentina assiduously. He also adhered with sincere conviction to the "Movimento per la Vita" in Florence for the rights of human life from conception to natural death and was one of the first supporters of the "Agata Smeralda Project" born in Florence, for the long distance adoption of poor and abandoned children, the "meniños de rua", of Brazil. In his commitments as volunteer and testimony, he always lived and worked in full agreement and sharing with his beloved wife, Matilde Pretto, married in 1965. Ilde, as she was affectionately called in the family, although from a different professional background, being a music teacher, as well as the skilled pianist herself, she faithfully accompanied him throughout his life both in the many excursions and naturalistic trips and in the various socio-cultural occasions typical of entomology meetings, conferences and congresses. Marco in turn shared a passion for music with his wife Ilde. All of Marco's colleagues and friends knew her well and all of them always had sincere relationships of esteem, sympathy and cordiality with her.

Finally, Marco was, and could not be otherwise, a man of prayer. If during the common excursions in the woods of our beautiful Italy we found ourselves at midday, he did not forget to propose the recitation of the Angelus to those who accompanied him.

Marco left his dear Ilde, who joined him in heaven shortly after, at the end of May, and his very affectionate children, Beatrice and Luigi. 
With Marco Vittorio Covassi, not only one of the main exponents of Italian entomological-forest research disappears but also a man of faith and charity, generous, a man of extraordinary inner wealth of affection, sentiment and humanity. His departure leaves a deep void in his family and in those who, like the writer, had the good fortune of having him not only as a teacher and work colleague but also, and above all, as a true and sincere friend.

\section{LIST OF PUBLICATIONS OF M.V. COVASSI}

1. CovaSSI M., 1966-1967 - Osservazioni su Strophosomus melanogrammus (Forst.), Polydrosus marginatus Steph. e Otiorrhinchus armadillo (Rossi) (Coleoptera Curculionidae), dannosi alla Pseudotsuga douglasii Carr. in Toscana.- Redia, L: 89-119.

2. CoVASSI M., 1968-1969 - Nuovi reperti sul Semanotus russicus (F.) in Italia e segnalazione della presenza di Semanotus laurasi (Luc.) in Sardegna (Coleoptera, Cerambycidae).- Redia, LI: 383-422.

3. ZOCCHI R., COVASSI M., 1968-69 - Reperti sulla corologia ed etologia del Phymatodes glabratus (Charp.) (Coleoptera Cerambycidae) in Italia.- Redia, LI: 259-268.

4. Zocchi R., Covassi M., 1971 - Reperti sulla corologia e sull'etologia del Phymatodes glabratus (Charp.) in Italia.- Atti VIII Congr.Naz.It.Ent., Firenze, 4-7 settembre 1969: 122-123.

5. CovaSSI M., 1970 - Attività varie, Sezione di Entomologia Forestale. In: Zocchi R., Relazione sull'attività di ricerca e sperimentazione svolta nel 1970.- Ann. I.S.Z.A., Firenze, vol. I: VII-XLI.

6. CovASSI M., 1970-71 - Osservazioni sulla biologia della Gilletteella coweni (Gill.) (Homoptera, Aphidoidea, Adelgidae) e sulla sua diffusione in Italia.- Ann. I.S.Z.A., Firenze, vol. I: XVII-XIX.

7. COVASSI M., 1971 - Prove di lotta chimica in vivaio contro la Gilletteella coweni (Gill.) (Homoptera Adelgidae). Annali I.S.Z.A., Firenze, II: 1-9.

8. CovASSI M., 1971 - Osservazioni preliminari sulla presenza in Italia di un afide nocivo ai cedri: Cedrobium laportei Remaud. (Homoptera, Aphididea, Lachnidae).- Redia, LII: 641-652.

9. Covassi M., MASuTTI L., 1973 - Sulla presenza della Thecodiplosis brachyntera (Schwaegr.) in pinete delle Alpi centro-orientali (Diptera, Cecidomyiidae).- Redia, LIV: 235-241.

10. CovaSSI M., 1974 - Il Demyrsus meleoides Pascoe: un potenziale nemico delle Cicadee ornamentali introdotto in Italia (Coleoptera, Curculionidae).- Redia, LV: 211-217.

11. Covassi M., BINAZZI A., 1974 - Note corologiche e morfologiche sulla Cinara cedri Mim. in Italia (Homoptera Aphidoidea Lachnidae).- Redia, LV: 331-341.

12. CovASSI M., $\mathbf{1 9 7 5}$ - Intervento alla tavola rotonda su $<<$ Rimboschimenti e conservazione dell'ambiente $>>$.- Inf.tore Bot.it., 7 (1): 83-84.

13. CoVASSI M., 1975 - Nuovi reperti sulla corologia del Cryptococcus fagisuga Lndgr. In Italia $\mathrm{e}$ in Corsica.- Ann.Ist.Sperim.Zool.Agr., 4: 389-398. Redia (1975), LVI: 555-564.

14. CoVASSI M., 1975 - Intervento alla tavola rotonda $\mathrm{su}<<$ Rimboschimenti e conservazione dell'ambiente $>>$. Inf.tore Bot.it., 7 (1):83-84.

15. Covassi M., InTINi M., PANCONESI A., $\mathbf{1 9 7 5}$ - Osservazioni preliminari sui rapporti fra Coryneum cardinale Wag. e Phloeosinus aubei Perr. in Toscana.- Redia, LVI: 159166.

16. Masutti L., CovasSi M., 1978 - Imenotteri Sinfiti di habitat forestali e montani del Friuli.- Redia, LXI: 107-174.

17. Tiberi R., Covassi M., Nota E., 1978 Cenni su gli Insetti più dannosi al Platano, con particolare riferimento alla Tingide americana.- Informatore Fitopatologico, n. 11/12, Anno XXVIII: 67-72.

18. CovaSSI M.. MASUTTI L., 1978-1979 Aperçu sur les principaux problèmes posés par les insectes forestiers en Italie.Ann.I.S.Z.A.,vol VI: 27-32.

19. CovaSSI M., BINAZZI A., 1979 - Gli insetti del cipresso più comuni e dannosi in Italia e cenni di lotta.- CEE/AGRIMED, Seminario: Il Cipresso, Malattie e Difesa, Firenze, 2324 novembre 1979, Pubbl. V.GRASSO e P.RADDI: 203-216.

20. Covassi M.. BINAZZI A., 1979 a - Gli insetti coinvolti nel deperimento del cipresso in Italia. Prospettive di lotta contro le specie più comuni e dannose.- ICE, Roma, Notiziario Ortofrutticolo e dei prodotti agricolo-alimentari e floricoli, Anno 31 ${ }^{\circ}$, n. 9: 22-26.

21. CovaSSI M., BINAZZI A., 1979 b - L'afide dei cipressi.- L'Informatore Agrario, n. 42, 1 novembre 1979, Rubrica "Lettere al Direttore": 7705.

22. Covassi M., BinAZZI A., $1979 \mathrm{c}-$ The most common and injurious cypress insects in Italy and some aspects of their control.- Seminario: Il Cipresso malattie e difesa, Firenze, 23-24 novembre 1979, CEE-AGRIMED: 12-13.

23. COVASSI M., 1980 - Sulla presenza dello Scolytus kirschi Skal. su Ulmus carpinifolia Gled. In Toscana (Coleoptera, Scolytidae).Redia, LXIII: 177-184. 
24. Covassi M., BinAZZI A., 1980 - Gli insetti coinvolti nel deperimento del cipresso in Italia: aspetti generali, cenni bio-ecologici, prospettive di lotta contro le specie più comuni e dannose.- Ed. Consulta per l'Agricoltura e le Foreste delle Venezie, "Agricoltura delle Venezie", Anno XXXIV, n.12: 586595.

25. Covassi M., MASUTTI L., 1980 - Generalità sull'entomofauna degli olmi con particolare riguardo agli scolitidi vettori della grafiosi.Inform.fitopatol., 30 (1): 19-26.

26. Masutti L., Covassi M., 1980 - Contributo alla conoscenza delle Hoplocampa Hartig italiane e descrizione di H. chamaemespili n.sp. (Hymenoptera, Tenthredinidae).- Redia, LXIII: 221-247.

27. CovasSi M., BINAZZI A., 1981 - Contributi alla conoscenza degli afidi delle conifere. IV. Note su alcune specie di Adelgidi reperite in Italia (Homoptera Adelgidae).- Redia, LXIV: 303-330.

28. CoVASSI M., 1982 - Gli insetti degli habitat forestali e montani nel quadro della conservazione della natura in Italia.- Famiglie Francescane Toscane. Convegno "Il Messaggio di San Francesco e l'Ecologia”, La Verna (AR), 14/16 settembre 1982: 83-88.

29. Covassi M., TIBERI R., 1982 - Note bioecologiche sulla Pristiphora abietina (Crist.) nell'Appennino settentrionale ((Hymenoptera, Symphyta, Tenthredinidae).- Redia, LXV: 367-376.

30. CovASSI M., 1983 - Il Cecidomiide degli aghi dell'abete Paradiplosis abietis (Hubault) nell'Italia meridionale.- Redia, LXVI: $1-8$.

31. CoVASSI M., 1983 - Sulla presenza dello Scolytus kirschi Skal. su Ulmus carpinifolia Gled. In Toscana (Coleoptera, Scolytidae).Atti XII Congr.naz.it.di Entomol., Roma, 59 novembre 1980. Vol II, Accademia naz. it. di Entomol., C.N.R., Roma, 1983:135-136.

32. CoVASSI M., 1985 - Piante minacciate nelle città e loro destino. Atti Convegno <<Entomologia urbana per la qualità della vita $>>$. In: Atti Acc.naz.it.entomol. Rendiconti, XXX-XXXII (1981-'84): 197-220.

33. CovasSi M., BINAZZI A., 1985 - Primi reperti su alcuni fitomizi dell'Abies nebrodensis (Lojac.) Mattei in Sicilia (Homoptera).Atti XIV Congr.Naz.It.Ent. (Palermo, Erice, Bagheria): 81-86.

34. CovASSI M., 1986 - Si chiama Matsucoccus feytaudi Ducasse ed è......- Agricoltura Liguria, Genova, IV, 1985 (11-12): 16-17.

35. Covassi M., Poggesi G., 1986 - Notizie sulla presenza e l'ecologia di Elatophilus pini (Baer.) in Italia (Heteroptera Anthocoridae).- Redia, LXIX. 1-10.

36. COVASSI M.,1987 - Gli insetti fitofagi del pino nero d'Austria, gli afidi delle conifere ed altri reperti entomologici. In: Aspetti Faunistici della Val d'Alba. Ed. Azienda Foreste Regione Friuli-Venezia Giulia, Udine (1987): 1-140.

37. CovaSSI M.,1987 - Aspetti dell'entomofauna forestale. In: Aspetti Faunistici della Val d'Alba. Ed. Azienda Foreste Regione Friuli-Venezia Giulia, Udine: 17-56.

38. BinazZI A., Covassi M., 1987 - Il Matsucoccus feytaudi Ducasse nelle pinete liguri di ponente. - Atti Convegno sulle Avversità del Bosco e delle Specie arboree da legno, Firenze, 15-16 ottobre 1987: 197-222.

39. BINAZZI A., CovasSi M., 1988 - Le specie del gen. Dreyfusia in Italia. Nota preliminare (Homoptera Adelgidae).- Atti XV Congr.naz.ital.Ent., L'Aquila,1988: 267273.

40. Covassi M., Roversi P.F., TOCCAFONDI P., 1989 - Danni da Haematoloma dorsatum (Ahrens) su conifere (Homoptera Cercopidae). I. Alterazioni macroscopiche degli apparati fogliari.- Redia, LXXII (1): 259-275.

41. Roversi P.F., Covassi M., TOCCAFONDI P., 1989 - Danni da Haematoloma dorsatum (Ahrens) su conifere (Homoptera Cercopidae). II. Indagine microscopica sulle modalità di penetrazione degli stiletti boccali.Redia, LXXII (2):

42. CovASSI M., 1989 - Gli insetti e l'alterata dinamica degli ecosistemi di foresta. Criteri per il riassetto delle entomocenosi. Atti Convegno avversità del bosco e delle specie arboree da legno. Accad.Naz.it.Ent. e Accad.Naz.it.Sci.Forest. (Firenze, 15-16 ott. 1987). Arti Graf. Giorgi \& Gambi, pp. 405447.

43. CoVASSI M., 1991 - Il Phloeosinus armatus Reitter, coleotero scolitide del cipresso, nuovo per l'Italia.- Il Cipresso, Proposte di valorizzazione ambientale e produttiva nei paesi mediterranei della Comunità Economica Europea, Firenze, 12-13 dicembre 1991, C.N.R., Comitato Nazionale per le Scienze Agrarie, Regione Toscana, C.E.E.Dir.Gen.Agric.:190-196.

44. Battisti A., Covassi M., 1991 - I principali insetti xilofagi viventi su querce in Italia e loro ruolo nei fenomeni di deperimento. In: A.Ragazzi, R. Tiberi (a cura di): Aspetti fitopatologici delle Querce (Atti Conv. $<<$ Problematiche fitopatologiche del gen. Quercus in Italia $>$. Firenze 19-20 nov. 1990). Stamperia Granducale, Firenze, pp. 251-272.

45. Battisti A., Covassi M., 1991 - Specie di Magdalis Germar e Pissodes Germar su pini dell'Italia appenninica (Coleoptera Curculionidae). Atti XVI Congr. Naz. It. Entomologia, Bari-Martina Franca (TA), 23-28 sett.1991, pp. 647-653.

46. BINAZZI A., CovaSSI M., 1991 - Contributi 
alla conoscenza degli afidi delle conifere.

XII. Il Gen. Dreyfusia Börner in Italia con la descrizione di una specie nuova (Homoptera Adelgidae).- Redia,vol.LXXIV,n.1: 233-299.

47. Covassi M., Binazzi A., TocCAFOndi P., 1991 - Studi sugli entomofagi predatori di cocciniglie del Gen. Matsucoccus Cock. in Italia. I. Note faunistico-ecologiche su specie osservate in pinete della Liguria e della Toscana.- Redia, vol. LXXIV, n.2: 575-598.

48. TocCAFOndi P., Covassi M., PENNACCHIO F., 1991 - Studi sugli entomofagi predatori di cocciniglie del Gen. Matsucoccus Cock. In Italia. II. Note bio-etologiche su Rhyzobius chrysomeloides (Herbst) in pinete della Liguria (Coleoptera Coccinellidae).- Redia, LXXIV, n. 2: 599-620.

49. Roversi P.F., Covassi M., TIBERI R., 1991 - Osservazioni sulla presenza e il numero di generazioni di Ooencyrtus kuwanae (Howard) in Italia.- Atti XVI Congr.naz.it.Ent., Bari-Martina Franca (TA), 23-28 settembre 1991: 429-435.

50. ROVERSi P.F., Covassi M., TOCCAFONDI P., 1991 - Distribuzione e Bioecologia di Haematoloma dorsatum in Italia. In: G. Govi, L. Masutti (a cura di): Atti delle giornate di studio sulle avversità del pino, Assessorato Agricoltura e Alimentazione Regione Emilia Romagna, Ravenna 6-7 novembre 1989, pp. 195-205.

51. CovASSI M., 1992 - Relazione su sopralluogo fitosanitario in Sila Grande, 13 maggio 1992.- I.S.Z.A., Sezione di Entomologia Forestale, 10 novembre 1992: 1-4.

52. Toccafondi P., Pennacchio F., Covassi $\underline{\text { M., }} 1992$ - Studi sugli entomofagi predatori di cocciniglie del Gen. Matsucoccus Cock. in Italia. III. Morfologia delle uova e modalità di ovideposizione in Elatophilus nigricornis (Zett.), E. pini (Baer) e Dufouriellus ater (Duf.) (Heteroptera Anthocoridae).Redia, LXXV:

53. Covassi M., BinaZZI A., 1992 - Primi focolai di Matsucoccus feytaudi Ducasse nella Liguria orientale (Homoptera Margarodidae).- Redia, LXXV, n. 2: 453-466.

54. FRANCARDi V., COVASSI M., 1992 - Note bio-ecologiche sul Planococcus vovae (Nasonov) dannoso a Juniperus spp. In Toscana (Homoptera Pseudociccidae).- Redia, LXXV, n.1: 1-20.

55. CovasSi M., BINAZZI A., 1993 - Principali insetti fitomizi dell'abete bianco in Italia: aspetti faunistico-ecologici e importanza forestale.- Atti Convegno "Le avversità delle abetine in Italia", Vallombrosa (FI), 25-26 giugno 1992, pp. 99-123.

56. CovASSI M., 1993 - Avversità biotiche e prospettive di controllo biologico ed integrato. Relazione introduttiva al Convegno
"Piante Forestali, avversita biotiche e prospettive di controllo biologico ed integrato", Firenze 5 marzo 1992, pp. 9-18.

57. Covassi M., TocCAFOndi P., BinAzZI A., 1993 - Principali insetti predatori della cocciniglia del pino marittimo Matsucoccus feytaudi in Liguria. In: M. Covassi (a cura di): Atti del Convegno "Piante Forestali, avversità biotiche e prospettive di controllo biologico ed integrato", Firenze 5 marzo 1992, pp. 101-108.

58. FRANCARdi V., Covassi M., 1993 - Osservazioni preliminari sull'Epinotia nigricana (H.S.) (Lepidoptera Tortricidae) nociva alla rinnovazione dell'abete bianco nell'Appennino toscano.- Atti del Convegno $<<$ Le avversità delle abetine in Toscana $>>$, Vallombrosa (FI), 25-26 giugno 1992: 227.236.

59. Roversi P.F., COVASSI M., TIBERI R., 1993 - Monitoraggio di Tortrix viridana con l'impiego di attrattivi sessuali e con altre tecniche in querceti della Toscana. In: M. Covassi (a cura di): Atti del Convegno "Piante Forestali, avversita biotiche e prospettive di controllo biologico ed integrato", Firenze 5 marzo 1992, pp. 109-115.

60. Roversi P.F., Covassi M., BINAZZI A., 1993 - Insetti fitofagi della Pseudotsuga menziesii (Mirb.) Franco var menziesii in Italia. In: Atti del Convegno "Le avversità delle abetine in Italia", Vallombrosa (FI) 2526 giugno 1992, pp. 125-140.

61. ROVERSI P.F., BACCETTI C., FABBRICATORE T., Covassi M., Nocentini S., 1993 - Entomofauna fitofaga della Pseudotsuga menziesii (Mirb.) Franco var. menziesii in aree appenniniche.- Ann.Ist.Sperim.Selvic., XXIV: 49-62.

62. CoVASSI M., 1994 - Matsucoccus feytaudi Ducasse. Risposta alla interrogazione in commissione di CECCHI ai Ministri dell'Ambiente e delle Risorse Agricole, Alimentari e Forestali. Camera dei Deputati, seduta del 21 ottobre 1994: pp. 1-5.

63. CovasSi M., TIBERI R., 1994 - Interventi integrati di controllo dei fitofagi forestali.Atti XVII Congr.naz.it. ent, Udine, 13-18 giugno 1994, Arti Grafiche Friulane, Udine:723-738.

64. BinaZZI A., Covassi M., 1994 - Contributi alla conoscenza degli afidi delle conifere. XIX. Annotazioni preliminari sugli Afidoidei del pino mugo in Italia (Homoptera Aphidoidea).- Redia, LXXVII, (2): 189-199.

65. Covassi M., FRANCARDI V., 1994 - Note sulla diffusione e sulla biologia di Argyresthia illuminatella Zeller in abetine dell'Italia centro- meridionale (Lepidoptera Argyresthiidae).- REDIA,Vol. LXXVII, 1: 123131.

66. FrancARdi V., CovasSi M.,1994 - Note 
sulla bioecologia di Epinotia nigricana (Herrich-Schaeffer) in abetine dell'Italia centrale (Lepidoptera Tortricidae). - REDIA, Vol.LXXVII, 1: 55-67.

67. Francardi V., Covassi M., De Silva J.,1994 - Valutazioni sull'attività di Epinotia nigricana (Herrrich-Schaeffer) (Lepidoptera Tortricidae) sulla rinnovazione naturale di Abies alba Miller in Toscana.- REDIA, Vol. LXXVII, 2: 375-386.

68. Roversi P.F., Covassi M., 1994 - Note ecologiche sui coleotteri xilofagi della douglasia in Italia.- Atti XVII Congresso nazionale italiano di Entomologia, Udine 13-18 giugno 1994: 767-770.

69. Roversi P.F., Covassi M., DE Silva J., BACCETTI C., FABBRICATORE T., 1994 - Monitoraggio di popolazioni di Tortrix viridana con l'impiego di attrattivi sessuali e di altre tecniche in querceti della Toscana.- Atti Convegno «Innovazione e prospettive nella difesa fitosanitaria», Ferrara 24-25 ottobre 1994: 333-337.

70. Binazzi A., Covassi M., Pennacchio F., 1995 - Contributi alla conoscenza degli afidi delle conifere. XXIII. Rilievi faunistico-ecologici sugli afidi del pino mugo appenninico (Homoptera Aphidoidea).- Redia, LXXVIII, n. 2: 293-301.

71. CovasSi M., Roversi P.F., 1995 - Problematiche entomologiche delle pinete di Monte Morello, Firenze.- L'Italia Forestale e Montana, L(6): 570-582.

72. Roversi P.F., BACCETTI C., COVASSI M., FABBricAtore T., NOCENTINI S., 1995 Entomofauna fitofaga della Pseudotsuga menziesii (Mirb.) Franco var. menziesii in aree appenniniche.- Annali dell'Istituto Sperimentale per la Selvicoltura, Arezzo, XXIV: 49-62.

73. Binazzi A., Covassi M., Pennacchio F., 1996 - The Aphids living on Pinus mugo Turra in Italy (Homoptera: Aphidoidea).Acta XX Intern. Congr. Entomol, Firenze, Italy, August 25-31, 1996: 532 (16-110).

74. Roversi P.F., Covassi M., BINAZZI A., FRANCARDI V., 1996 - Pest management of Tortrix viridana (L.): monitoring populations with pheromone traps (Lepidoptera Tortricidae).- Acta XX Intern. Congr. Entomol, Firenze,Italy, August 25-31, 1996: 523 (16-076).

75. BinazZI A., Covassi M. V., 1997 - Gli afidoidei ovipari in Italia: profilo storico, faunistica e bioecologia.- Atti Acc. Naz. It. Entom. Rendiconti, Anno XLV: 223-252.

76. Covassi M. V., Marinari Palmisano A., 1997 - Relazioni fra Nematodi ed Artropodi negli ecosistemi forestali. Atti del $1^{\circ}$ Congresso SISEF "La ricerca italiana per le foreste e la selvicoltura" Legnaro (PD) $4-6$ giugno 1997 (Ed. a cura di M. Borghetti): 95-100.

77. Covassi M.V., 1998 - Conclusioni del Convegno.- Atti della giornata di studio e aggiornamento sulle avversità del Cupressus sempervirens L., 14 maggio 1998, Firenze: 101-102.

78. CovasSi M., MASUTTI L., 1998 - La protezione del patrimonio forestale dagli artropodi dannosi.- Atti II Congr. Naz. Selvic. $<<$ Miglioramento e conservazione dei boschi italiani $>$. Accad.It.Sci.for., 3: 301333.

79. Binazzi A., Covassi M.V., 1998 - Note preliminari sugli afidi del Pinus leucodermis Antoine in Italia (Homoptera: Aphididae).Atti XVIII Congr. Naz. It. Ent., Maratea, 2126 giugno 1998, in: Supplm. Atti Accad. Naz. Ent., Rendic., a. XLVI, 1998: 40.

80. BINAZZI A., Covassi M.V., Roversi P.F., 1998 - Ruolo di Cinara cupressi e di altri insetti fitomizi nel deperimento del cipresso nostrale.- "Il nostro amico cipresso", Giornata di studio e aggiornamento sulle avversità del Cupressus sempervirens L., Firenze, 14 maggio 1998, Accademia Italiana di Scienze Forestali, Ann. A.I.S.F.: 55-66.

81. Covassi M.V., Roversi P.F., BinazZI A., 1998 - Diffusione e risposte adattative di insetti xilofagi nel mutato quadro fitosanitario di Cupressus sempervirens.- "Il nostro amico cipresso", Giornata di studio e aggiornamento sulle avversità del Cupressus sempervirens L., Firenze, 14 maggio 1998, Accademia Italiana di Scienze Forestali, Ann. A.I.S.F.: 77-91.

82. CoVASSI M.V, 1998 - preparazione degli Atti del Convegno nazionale "Il nostro amico cipresso. Giornata di studio e aggiornamento sulle avversità del Cupressus sempervirens (L.)". Annali dell'Accademia Italiana di Scienze Forestali, vol. 1998 (47).

83. Covassi M.V., MASUtTI L., 1998 - La protezione del patrimonio forestale dagli artropodi dannosu.- Atti II $^{\circ}$ Congr.Naz.Selv., Venezia, 24-27 giugno 1998: 301-333.

84. Roversi P.F., COVASSI M.V., 1998 (a cura di) - Il nostro amico cipresso.- Atti della giornata di studio e aggiornamento sulle avversità del Cupressus sempervirens L., 14 maggio 1998, Firenze: 1-103.

85. BinazZI A., FranCARdi V., CovasSi M.V., PENNACCHIO F., LECCESE A., 1999 - Invasioni biologiche e alterazioni degli equilibri biocenotici. Un caso eclatante: il Matsucoccus feytaudi Duc. nelle pinete di pino marittimo della Liguria.- Atti II Congr. S.I.S.E.F., 20-22 ottobre 1999, Bologna: 459-462 (pubbl. luglio 2000).

86. Binazzi A., Covassi M.V., Francardi V., ROVERSI P.F., PENNACCHIO F., 2000 - La 
cocciniglia del pino marittimo, Matsucoccus feytaudi Ducasse (Homoptera Coccoidea Margarodidae).- Campagna di Informazione a cura di Regione Toscana, Giunta Regionale, Dip. Sviluppo Economico, Serv. Foreste e Patrimonio Agroforestale, ARPAT, ISZA, Sez. ENT.F.: 1-4.

87. Mantovani B., Francardi V., LeCCESE A., BinAZZI A., Covassi M. V., 2001 - The genus Dreyfusia in Italy: a molecular approach (Hom. Aphidoidea Adelgidae).- Abstr. Sixth Intern. Symp. on Aphids, "Aphids in a New Millenium”, Rennes (France), 3-7 September 2001: 57.

88. Covassi M.V., MasutTi L., Tiberi R., 2002 - Entomologia Forestale in ambienti mediterranei.- XIX Congr.naz.it.Ent., Catania, 10-15 giugno 2002. Riass.Contr.Sci.: 173.

89. MASUTTI L., COVASSI M.V., 2002 - Rodol- fo Zocchi, In Memoriam.- Atti Acc. Naz. It. Ent., Anno L: 77-93.

90. Pennacchio F., Covassi M.V., FranCARDI V., BINAZZI A., ROVERSI P.F., 2006 I coleotteri xilofagi dei popolamenti di pino marittimo della Liguria e della Toscana attaccati da Matsucoccus feytaudi Duc. (Homoptera Margarodidae).- Redia, LXXXVIII, 2005, Appendice: 1-7.

91. Covassi M.V., ROVERSI P.F., PENNACCHIO F., BINAZZI A., FRANCARDI V., 2007 - Stato fitosanitario dei boschi e suscettibilità agli incendi in relazione all'attività delle entomofaune fitofaghe.- In: Fondazione S. Giovanni Gualberto, Osservatorio Foreste e Ambiente, I Quaderni n. 5, "L'opera di prevenzione degli incendi e l'educazione ambientale".- Atti Conv. 22-23 giugno 2006, Vallombrosa: 73-94. 